\title{
Aplikasi Kamus Bahasa Daerah Serawai Menggunakan Algoritma Bubble Sort dan Voice Recognition Berbasis Android
}

\author{
Ujang Juhardi ${ }^{1}$, Eka Sahputra ${ }^{2}$ \\ 1,2Dosen Tetap Program Studi Teknik Informatika Fakultas Teknik Universitas Muhammadiyah Bengkulu \\ Alamat Jl. Bali Kota Bengkulu; e-mail: ujangjuhardi@umb.ac.id ${ }^{1}$, ekasahputra@umb.ac.id ${ }^{2}$
}

\begin{abstract}
Bengkulu speak Malay Language as their first language or mother tongue. But, actually each region in Bengkulu has different regional languages. There are particularly nine regional languages in Bengkulu; they are Serawai language, Pekal language, Rejang language, Pasemah language, Mulak language, Kaur Bintuhan language, Bengkulu Malay language, Enggano language, and muko-muko language. At first to look for the serawai language translations, no one had ever used the facilities of a conventional dictionary and online internet dictionary directory. So it is necessary to make an innovation in the development of the Serawai language dictionary application to simplify the search by using the facility of updating database content and voice recognition. Therefore, it is expected that this application can be a useful and appropriate media for users. The problem of the research is how to make Serawai Regional Language Dictionary Using Bubble Sort Algorithm and Android-based Voice Recognition. The benefit of this research is to make it easy for the South Bengkulu district government to introduce the Serawai regional language to the wider community by utilizing android-based information technology.
\end{abstract}

Keywords: Application, Dictionary, Serawai, Android

Intisari-Secara umum memang masyarakat asli Sumatera berbahasa ibu (B1) rumpun bahasa Melayu. Tiap daerah di Sumatera umumnya memiliki bahasa daerah yang berbeda-beda. Khususnya di Bengkulu terdapat sembilan bahasa daerah yakni bahasa Serawai, bahasa Pekal, bahasa Rejang, bahasa Pasemah, bahasa Mulak, bahasa Kaur Bintuhan, bahasa Melayu Bengkulu, bahasa Enggano, dan bahasa Muko-muko. Pada awalnya untuk mencari terjemahan bahasa serawai belum pernah ada yang menggunakan fasilitas kamus konvensional dan direktori kamus online internet. Maka perlu dilakukan inovasi pengembangan aplikasi kamus bahasa serawai untuk mempermudah pencarian dengan disertai fasilitas konten update database dan pengenalan suara. Oleh karena itu diharapkan dengan dibuatnya aplikasi ini dapat menjadi media yang bermanfaat dan sesuai yang dibutuhkan oleh pengguna. Maka dirumuskan masalah bagaimana membuat Kamus Bahasa Daerah Serawai Menggunakan algoritma Bubble Sort dan Voice Recognition Berbasis Android. Dalam metode pengumpulan data digunakan observasi, studi pustaka. Manfaat penelitian ini untuk memberikan kemudahan bagi pemerintah daerah Kabupaten Bengkulu Selatan dalam memperkenalkan bahasa daerah Serawai pada masyarakat luas dengan memanfaatkan teknologi informasi berbasis android

Kata Kunci : Aplikasi, Kamus, Serawai, Android

\section{PENDAHULUAN}

Pada era komputerisasi ini, teknologi informasi khususnya komputer dan smartphone telah berkembang dengan sangat pesat dan telah melekat dengan kehidupan masyarakat. Saat ini komputer tidak hanya digunakan oleh para programmer saja tetapi juga digunakan oleh orang awam. Banyak sekali buku kamus istilah bahasa yang beredar tetapi buku tersebut justru menyulitkan karena pengguna harus mencari arti dari istilah komputer secara manual.

Penduduk kota Bengkulu adalah heterogen dilihat dari suku dan daerah asalnya. Selain penduduk asli (suku asli Melayu Bengkulu), mayoritas penduduknya berasal dari Sumatera Barat, Sumatera Selatan, dan Jawa (bahasa Jawa dan bahasa Sunda). Selain itu, beberapa penduduk kota Bengkulu juga berasal dari berbagai pelosok Sumatera, yakni dari Lampung, Pekanbaru, Jambi, Medan dan Aceh. Jelas sekali bahwa penduduk kota Bengkulu tidak berbeda keragaman asalnya dengan keragaman asal penduduk yang ada pada kota-kota di Indonesia.

Secara umum memang masyarakat asli Sumatera berbahasa ibu (B1) rumpun bahasa Melayu. Tiap daerah di Sumatera umumnya memiliki bahasa daerah yang berbeda-beda. Khususnya di Bengkulu terdapat sembilan bahasa daerah yakni bahasa Serawai, bahasa Pekal, bahasa Rejang, bahasa Pasemah, bahasa Mulak, bahasa Kaur Bintuhan, bahasa Melayu Bengkulu, bahasa Enggano, dan bahasa Muko-muko. Penduduk pendatang di kota Bengkulu tidak menggunakan bahasa daerah asal sebagai bahasa ibu. Pemakai bahasa ibu memang heterogen dan tidak ada yang dominan. Oleh karena itu, masyarakat kota Benkulu (asal dan pendatang) menggunakan bahasa 
Melayu Bengkulu sebagai bahasa untuk berkomunikasi bahasa kedua. Mengingat pemakai bahasa daerah yang beragam tersebut, penduduk pendatang yang mendidik anak berbahasa ibu bahasa Indonesia umumnya memperoleh bahasa kedua (B2) adalah bahasa Melayu Bengkulu.

Pada awalnya untuk mencari terjemahan bahasa serawai belum pernah ada yang menggunakan fasilitas kamus konvensional dan direktori kamus online internet. Maka perlu dilakukan inovasi pengembangan aplikasi kamus bahasa serawai untuk mempermudah pencarian dengan disertai fasilitas konten update database dan pengenalan suara. Oleh karena itu diharapkan dengan dibuatnya aplikasi ini dapat menjadi media yang bermanfaat dan sesuai yang dibutuhkan oleh pengguna.

\section{LANDASAN TEORI}

\section{A. Aplikasi}

Aplikasi berasal dari kata application yang artinya penerapan, lamaran, penggunaan. Secara istilah aplikasi adalah program siap pakai yang direka untuk melaksanakan suatu fungsi bagi pengguna atau aplikasi yang lain dan dapat digunakan oleh sasaran yang dituju. Perangkat lunak aplikasi adalah suatu subkelas perangkat lunak komputer yang memanfaatkan kemampuan komputer langsung untuk melakukan tugas yang diinginkan pengguna. Contoh utama perangkat lunak aplikasi adalah pengolah kata, lembar kerja, dan pemutar media[1].

\section{B. Kamus}

Kamus digital ialah sebuah buku yang memuat kumpulan istilah atau nama yang disusun menurut abjad dengan menggunakan teknologi komputer dan alat elektronik. Kamus digital lebih mengutamakan pada fasilitas pengola kata elektronis yaitu sebuah fasilitas yang memungkinkan pengguna aplikasi pengolah kata memeriksa ejaan dari okumen yang ia ketik. Hal ini dapat meminimumkan kemungkinan salah eja kata atau salah ketik [2].

\section{Algoritma}

Algoritma adalah urutan logis langkah-langkah penyelesaian masalah. Masalah tersebut dapat berupa apa saja, dengan catatan untuk setiap masalah, ada kriteria kondisi awal yang harus dipenuhi sebelum menjalankan algoritma. Algoritma akan dapat selalu berakhir untuk semua kondisi awal yang memenuhi kriteria, dalam hal ini berbeda dengan heuristik. Algoritma sering mempunyai langkah pengulangan (iterasi) atau memerlukan keputusan (logika Boolean dan perbandingan) sampai tugasnya selesai [3].

\section{Bubble sort}

Algoritma pengurutan apung (bubble sort) diinspirasi oleh gelembung sabun yang berada di atas permukaan air. Berat jenis gelembung sabun lebih ringan daripada berat jenis air, maka gelembung sabun selalu terapung ke atas permukaan. Secara umum, benda-benda yang berat akan terbenam dan benda-benda yang ringan akan terapung ke atas permukaan.Prinsip pengapungan di atas juga digunakan pada pengurutan apung. Apabila menginginkan larik terurut menaik, maka elemen larik yang berharga paling kecil "diapungkan", artinya diangkat ke "atas" (atau ke ujung kiri larik) melalui proses pertukaran. Proses pengapungan ini dilakukan sebanyak n - 1 langkah (satu langkah

Disebut juga satu kali pass) dengan $\mathrm{n}$ adalah ukuran larik. Akhir setiap langkah ke-i, larik L[1..n] akan terdiri atas dua bagian yaitu bagian yang sudah terurut, yaitu L[1..i], dan bagian yang belum terurut, L[i+1..n] (Gambar 1) setelah terakhir, diperoleh larik $L[1 . . n]$ yang terurut menaik.

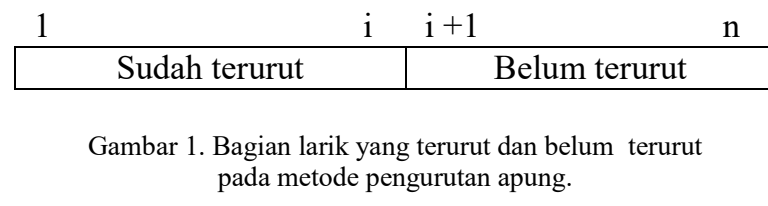

Pengurutan apung merupakan algoritma pengurutan yang tidak mangkus (efficient). Hal ini, disebabkan oleh banyaknya operasi pertukaran yang dilakukan pada setiap langkah pengapungan. Pengurutan dengan algoritma ini membutuhkan waktu yang lama untuk ukuran larik besar. Disebabkan alasan itu, maka algoritma pengurutan apung 
jarang digunakan dalam praktek pemrograman. Namun kelebihan algoritma ini adalah pada kesederhanaan dan udah dipahami[4].

\section{E. Voice Recognition}

Sistem pengenalan suara (voice recognition) merupakan gabungan dari sistem pengenalan pembicara (speaker recognition) Sistem Verifikasi Penutur menggunakan Metode Mel Frequensi dan pengenalan ucapan (speech recognition). Secara umum suatu sistem pengenalan ucapan, yang merupakan bagian dari pengenalan suara, terdiri atas dua proses utama. Proses pertama adalah ekstraksi parameter dan proses kedua adalah pencocokan pola [5].

\section{F. Android}

Android adalah sistem operasi yang berbasis Linux untuk telepon seluler seperti telepon pintar dan komputer tablet. Android menyediakan platform terbuka bagi para pengembang untuk menciptakan aplikasi mereka sendiri untuk digunakan oleh bermacam peranti bergerak. Awalnya, Google Inc. membeli Android Inc, pendatang baru yang membuat peranti lunak untuk ponsel. Kemudian untuk mengembangkan Android, dibentuklah Open Handset Alliance, konsorsium dari 34 perusahaan peranti keras, peranti lunak, dan telekomunikasi, termasuk Google, HTC, Intel, Motorola, Qualcomm, T-Mobile, dan Nvidia[6].

\section{G. UML}

Unified Modelling Language (UML) adalah sebuah "bahasa" yang telah menjadi standar dalam industry untuk visualisasi, merancang dan mendokumentasikan sistem piranti lunak. UML menawarkan sebuah standar untuk merancang model sebuah sistem. Dengan menggunakan UML dapat dibuat model untuk semua jenis aplikasi piranti lunak, dimana aplikasi tersebut dapat berjalan pada piranti keras, sistem operasi dan jaringan apapun, serta ditulis dalam bahasa pemrograman apapun [7].

\section{Metodelogi Penelitian}

Adapun Metode penelitian yang penulis gunakan adalah Rapid Aplication Development (RAD) merupakanstrategi pengembangansistem yang menekankan kecepatan pengembangan melalui keterlibatan pengguna yang ekstensif dalm konstruksi, cepat, berulang dan bertambah serangkaian prototype bekerja sebuah sistem yang pada akhirnya berkembang didalam sistem final. Berikut ini adalah gambaran kerangka pemikiran dari Rapid Aplication Development (RAD).

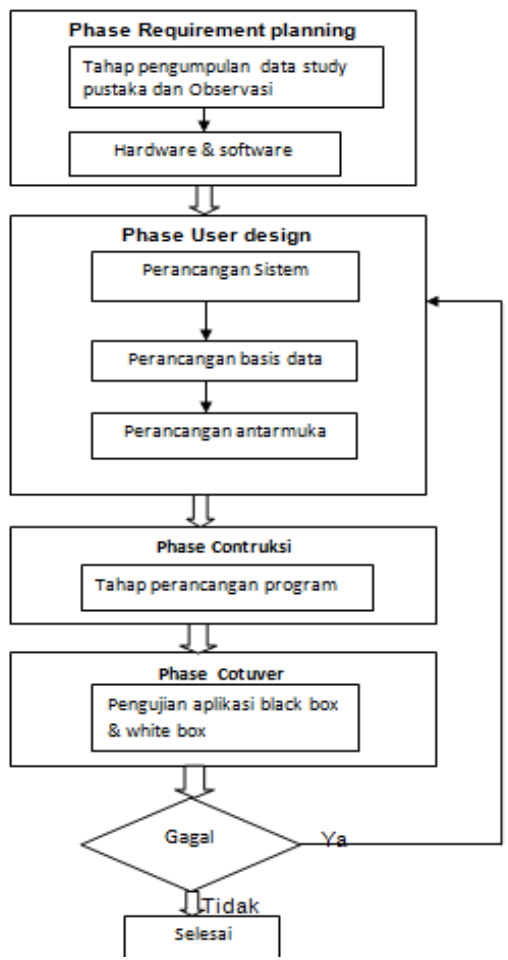

Gambar 2. Metode RAD

\section{A. Use case Diagram}

Use case diagram adalah gambaran graphical dari beberapa atau semua actor, use case, dan interaksi diantara komponen-komponen tersebut yang memperkenalkan suatu sistem yang akan dibangun digunakan untuk menjelaskan bagaimana langkah-langkah yang seharusnya dikerjakan oleh sistem

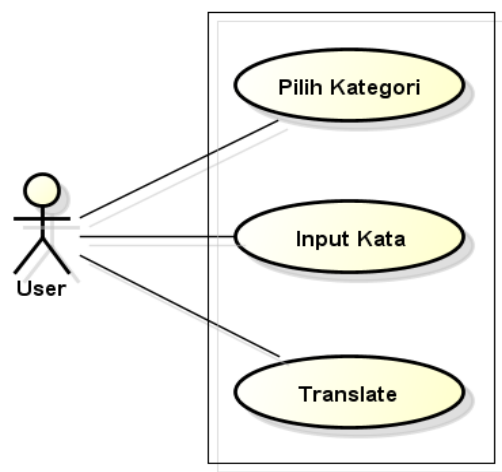

Gambar 3. Use case diagram 


\section{B. Activity Diagram}

Diagram Aktivitas menggambarkan berbagai aliran aktivitas dalam sistem yang sedang dirancang, bagaimana masing-masing alir berawal, decision yang mungkin terjadi dan akhir dari aktivitas. Activity diagram juga dapat menggambarkan proses paralel yang mungkin terjadi pada beberapa eksekusi
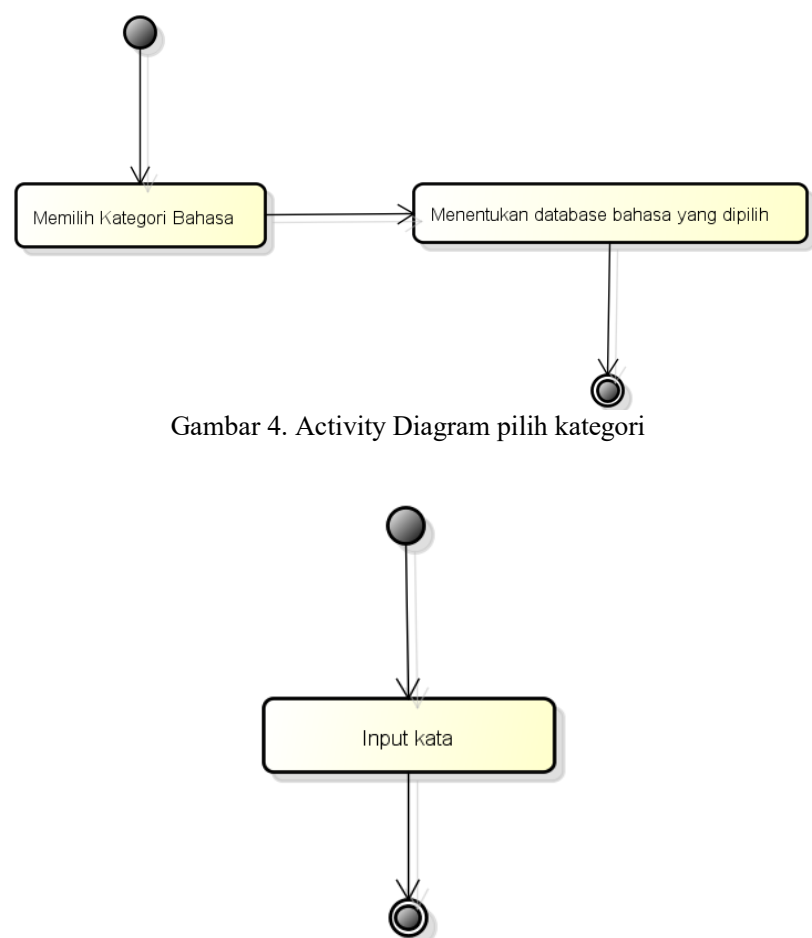

Gambar 5. Activity Diagram input kata

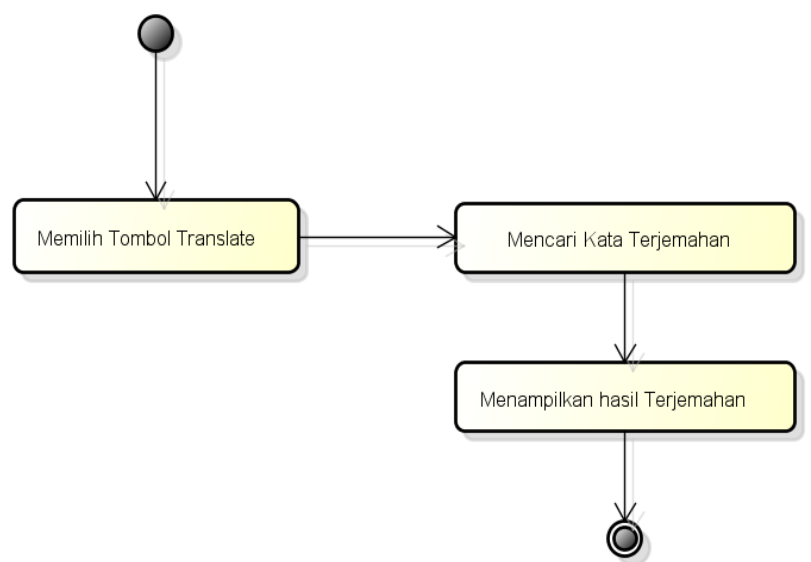

Gambar 6. Use case diagram translate

\section{IV.HASIL DAN PEMBAHASAN}

\section{A. Hasil dan Pembahasan Sistem}

Algoritma bubble sort melakukan pengurutkan bilangan diperlukan variabel array untuk menampung semua bilangan yang akan diurutkan. Proses pengurutan dilakukan dengan membandingkan semua elemen array satu per satu. Adapun contoh dalam penelitian ini adalah

\begin{tabular}{|c|c|c|c|c|c|c|c|c|}
\hline B & e & g & h & u & s & I & a & k \\
\hline 2 & 5 & 7 & 8 & 21 & 19 & 9 & 1 & 11 \\
\hline
\end{tabular}

Proses pengurutan dimulai dengan membandingkan elemen pertama untuk mendapatkan angka pertama, kemudian mencari angka yang terdapat pada database. Kemudian melakukan pengurutan pada elemen ke 2 sehingga mendapatkan sebuah kata Beghusiak.

Penerapan voice recognition pada aplikasi ini terletak pada pembacaan suara yang telah dikonversikan pada ejaan huruf, dimana pada aplikasi eclipse indigo memeiliki fitur yang dapat membaca konversi ejaan huruf tersebut. Namun sebelum mengaktifkan fitur tersebut, terlebih dahulu mendapatkan SH1 perangkat yang digunakan. Lalu mendaftar pada android.developer.google.com untuk mendaftarkan package name yang terdapat pada aplikasi. Sehingga aplikasi dapat mendikte dan mengedit teks.

Menggunakan Speech Recognition untuk mendikte kata-kata ke dalam program pengolah kata atau mengisi formulir online di web browser dalam menggunakan perangkat microphone sehingga suara dapat terekam dan diketahui ejaan dari suara tersebut. Dalam penelitian ini, memanfaatkan microphone dari smartphone sehingga suara yang dikeluarkan dapat diketahui ejaannya.

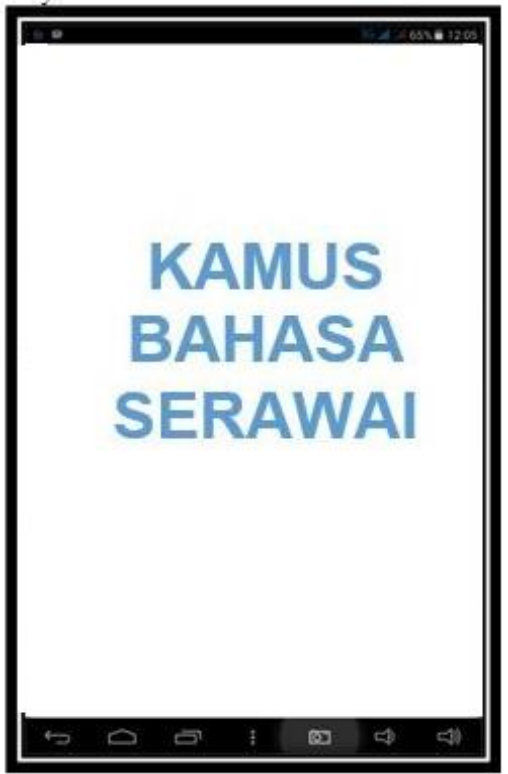

Gambar 7. Tampilan Awal 
MainActivity.java merupakan tampilan awal setelah splashscreen. Pada tampilan ini merupakan pusat kontrol aplikasi akan memiliki fungsi dari setiap tombol. Adapun tampilan MainActivity adalah sebagai berikut :

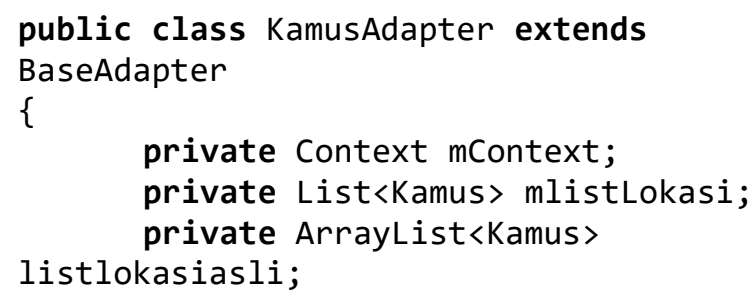

public KamusAdapter(Context context, List<Kamus> list) \{ mContext = context; mlistLokasi = list;//list;

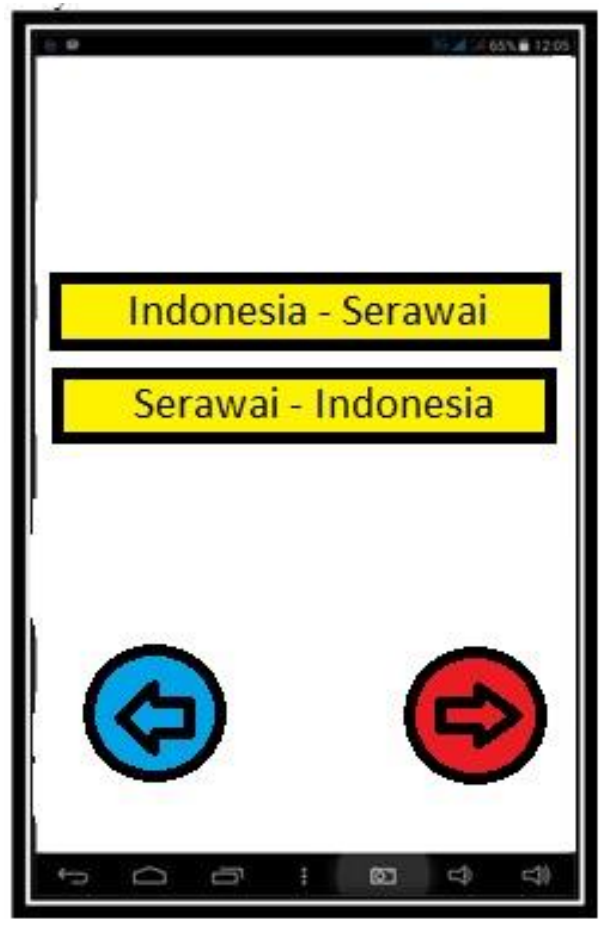

Gambar 8. Tampilan Menu

Proses pengurutan memakai variabel array untuk menampung semua bilangan yang akan diurutkan. Oleh karena itu sebelum proses pengurutan dilakukan, terlebih dahulu dibuat proses untuk mengisi semua bilangan ke dalam array.

Setelah array tersebut terisi, barulah proses pengurutan dilakukan untuk mengurutkan isinya. Seperti diketahui, jika salah satu elemen array diisi dengan nilai baru, maka nilai lama akan terhapus. Oleh sebab itu untuk mempertukarkan isi elemen array harus mengggunakan satu variabel cadangan. Variabel ini digunakan untuk menyimpan isi array yang akan ditukar. Adapun penjelasan tampilan Indonesia - Serawai pada gambar 4.2 adalah sebagai berikut :

1. Terdapat tombol $\mathrm{A}-\mathrm{Z}$ yang berfungsi kata mulai huruf A sampai Z. $\quad$ \}

2. Pada form input kata pencarian digunakan untuk pencarian kata.

3. Tombol cari digunakan untuk mencari kata terjemahan Indonesia - Serawai

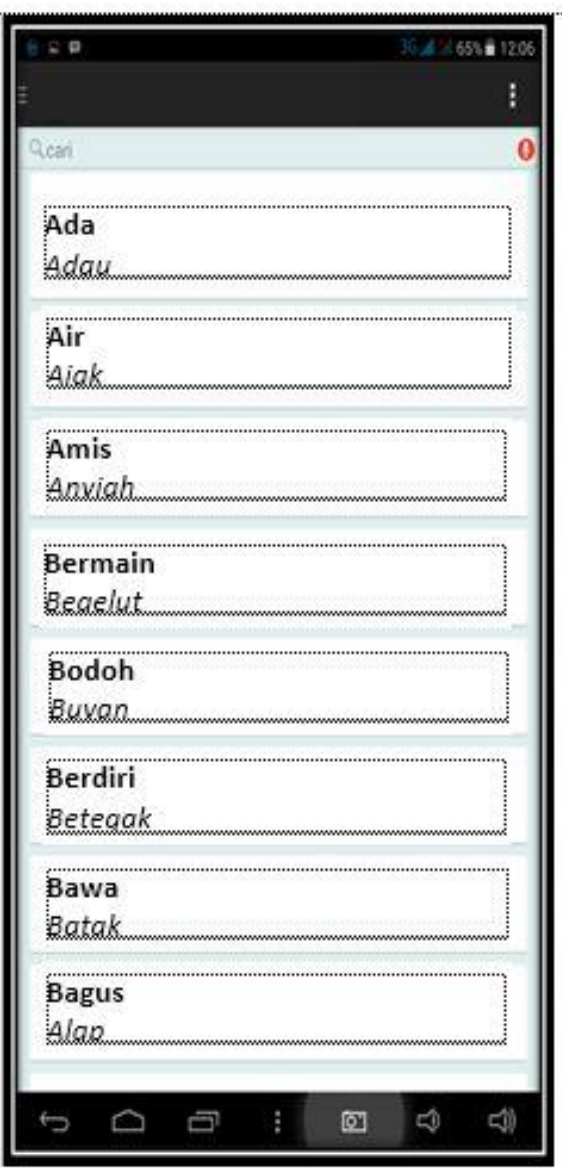

Gambar 9. Indonesia serawai

Pemanggilan string pada field indonesia dan Serawai. Algoritma bubble sort terdapat pada activity ini. Sehingga penerapan algoritma bubble sort dan voice recognition terdapat pada KamusIndoSerawai.java dan KamusSerawaiIndo.java. adapun tampilan KamusIndoSerawai dan KamusSerawaiIndo adalah sebagai berikut : 
public class KamusIndoSerawai extends Fragment \{

DBHelper db;

private ListView lvkamus;

private EditText inputCari;

public KamusAdapter adapter;

private static final int

$\underline{\text { SPEECH REQUEST CODE }}=0$;

private final int

REQ_CODE_SPEECH_INPUT $=100$;

private final int MENU_COPY $=1$;

private final int MENU_SHARE = 2;

ImageButton btnVoice;

String kataTerpilih;

String deskripsiTerpilih;

db. openDataBase () ;

$\mathrm{dbl}=\mathrm{db}$.getReadableDatabase () ;

String sql = " select * from kamus order by indonesia ";

Log.d("sql", sql);

null) ;

Cursor $\mathrm{c}=\mathrm{dbl}$.rawQuery (sql,

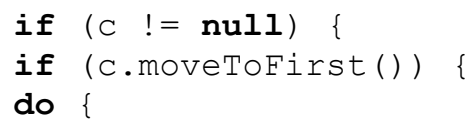

lsLokasi.add (new

Kamus (

c.getstring (c.getColumnIndex ("idk amus")), c.getstring(c

.getColumnIndex ("indonesia")), c.getstring ( c

-getcolumn Index ("serawai"))

)) ;

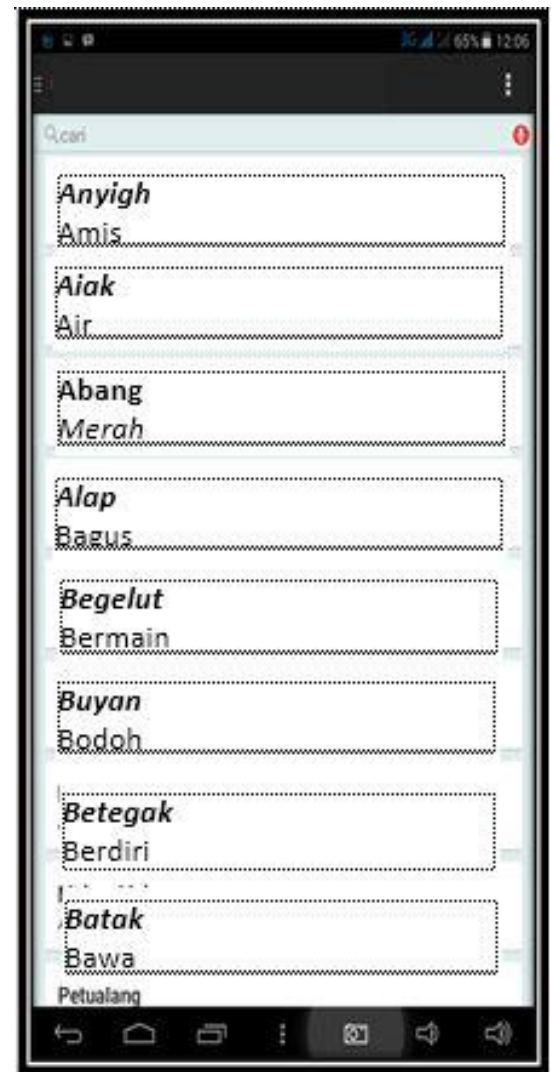

Gambar 10. Serawai Indonesia

\section{B. Pengujian Sistem}

Adapun hasil pengujian aplikasi Kamus Bahasa Daerah Serawai Menggunakan algoritma Bubble Sort dan Voice Recognition Berbasis Android. Adapun pengujian sistem adalah sebagai berikut :

a. Blackbox Testing

\begin{tabular}{|c|c|c|c|}
\hline $\begin{array}{l}\text { Proses } \\
\text { yang } \\
\text { diuji }\end{array}$ & $\begin{array}{c}\text { Skenario } \\
\text { Pengujian }\end{array}$ & $\begin{array}{l}\text { Hasil yang } \\
\text { diharapkan }\end{array}$ & $\begin{array}{c}\text { Hasil } \\
\text { Pengujian }\end{array}$ \\
\hline $\begin{array}{l}\text { Tombol } \\
\text { Indonesia } \\
- \\
\text { Serawai }\end{array}$ & $\begin{array}{l}\text { Muncul } \\
\text { informasi } \\
\text { bahasa } \\
\text { indonesia } \\
\text { kemudian } \\
\text { translate } \\
\text { bahasa } \\
\text { serawai }\end{array}$ & $\begin{array}{l}\text { Terdapat } \\
\text { informasi } \\
\text { bahasa } \\
\text { indonesia dan } \\
\text { bahasa } \\
\text { serawai }\end{array}$ & $\begin{array}{l}\text { Sesuai yang } \\
\text { diharapkan }\end{array}$ \\
\hline $\begin{array}{l}\text { Tombol } \\
\text { Serawai - } \\
\text { Indonesia }\end{array}$ & $\begin{array}{l}\text { Muncul } \\
\text { informasi } \\
\text { bahasa } \\
\text { serawai } \\
\text { kemudian } \\
\text { translate } \\
\text { bahasa } \\
\text { indonesia }\end{array}$ & $\begin{array}{l}\text { Terdapat } \\
\text { informasi } \\
\text { bahasa } \\
\text { serawai dan } \\
\text { bahasa } \\
\text { indonesia }\end{array}$ & $\begin{array}{l}\text { Sesuai yang } \\
\text { diharapkan }\end{array}$ \\
\hline $\begin{array}{l}\text { Jika } \\
\text { Pencarian } \\
\text { Tidak } \\
\text { ada }\end{array}$ & $\begin{array}{l}\text { Akan } \\
\text { muncul } \\
\text { pesan dialog }\end{array}$ & $\begin{array}{l}\text { Terdapat } \\
\text { pesan } \\
\text { "pencarian } \\
\text { kata tidak } \\
\text { ditemukan" }\end{array}$ & $\begin{array}{l}\text { Sesuai yang } \\
\text { diharapkan }\end{array}$ \\
\hline
\end{tabular}

b. Whitebox Testing

\begin{tabular}{|l|l|l|l|l|}
\hline \multirow{2}{*}{ No } & \multirow{2}{*}{ Kriteria } & \multicolumn{3}{|l|}{ Persentase \% } \\
\cline { 3 - 5 } & & SM & M & TM \\
\hline 1 & $\begin{array}{l}\text { Program bersifat } \\
\text { Interaktif dan } \\
\text { Dinamis }\end{array}$ & 15 & 4 & 1 \\
\hline 2 & $\begin{array}{l}\text { Aplikasi membantu } \\
\text { informasi bahasa } \\
\text { serawai }\end{array}$ & 16 & 4 & 0 \\
\hline 3 & $\begin{array}{l}\text { Bagaimana } \\
\text { penerapan sorting } \\
\text { pada kamus Bahasa } \\
\text { serawai sesuai } \\
\text { dengan kebutuhan }\end{array}$ & 5 & 14 & 1 \\
\hline 4 & $\begin{array}{l}\text { Warna tampilan } \\
\text { menarik }\end{array}$ & 5 & 10 & 5 \\
\hline 5 & $\begin{array}{l}\text { Menu tampilan } \\
\text { bersifat } \text { user friendly }\end{array}$ & 6 & 13 & 1 \\
\hline Jumlah Responden & 20 & & \\
\hline
\end{tabular}

Keterangan

1. Jumlah Pernyataan a. Sangat Menarik $(\mathrm{SM})=47$

Pernyataan 


\section{b. $\quad$ Menarik $(M)=45$ Pernyataan \\ c. $\quad$ Tidak Menarik $(\mathrm{TM})=8$ Pertanyaan \\ Total $=100$ Pernyataan}

2. Jumlah Responden 20 Responden

Maka diperoleh jawaban sangat menarik $47 \%$, menarik 45 \%, dan tidak menarik 8\%. Adapun cara perhitungannya adalah sebagai berikut :

1. Hitung setiap row pernyataan kemudian pernyataan dijumlahkan.

2. Lakukan penghitungan

a. Sangat Menarik

$$
\frac{47}{100} \times 100=47 \%
$$

b. Menarik

$$
\frac{45}{100} \times 100=45 \%
$$

c. Tidak Menarik

$$
\frac{8}{100} \times 100=8 \%
$$

\section{Penutup}

\section{A. Kesimpulan}

Kesimpulan yang dapat ditarik dari aplikasi Kamus Bahasa Daerah Serawai Menggunakan algoritma Bubble Sort dan Voice Recognition Berbasis Android, adalah sebagai berikut :

1. Memberikan kemudahan bagi pemerintah daerah Kabupaten Bengkulu Selatan dalam memperkenalkan bahasa daerah Serawai pada masyarakat luas dengan memanfaatkan teknologi informasi berbasis android.

2. Untuk pengembangan aplikasi kamus bahasa serawai untuk mempermudah pencarian dengan disertai fasilitas konten update database dan pengenalan suara. Oleh karena itu diharapkan dengan dibuatnya aplikasi ini dapat menjadi media yang bermanfaat dan sesuai yang dibutuhkan oleh pengguna

\section{B. Saran}

Dari kesimpulan diatas, ada beberapa saran agar dapat menggunakan program aplikasi ini dengan maksimal.

1. Diharapkan aplikasi ini selalu up to date sehingga aplikasi ini mengikuti perkembangan teknologi informasi pendidikan dan kebudayaan

2. Diharapkan pengembangan aplikasi ini dapat menjadi referensi bukan hanya dunia pendidikan khususnya pelajaran daerah melainkan juga untuk semua pelajaran dan semua kalangan sebagai perkemangan informasi teknologi.

\section{DAfTAR PUStaka}

[1] Sianturi, F. A. (2013). Perancangan aplikasi pengamanan data dengan kriptografi Advanced Encryption Standard (AES). Pelita Informatika: Informasi dan Informatika, 4(1).

[2] Gunawan, G. (2016). APLIKASI KAMUS ISTILAH EKONOMI (INGGRIS-INDONESIA) MENGGUNAKAN METODE SEQUENTIAL SEARCHING. Jurnal pseudocode, 3(2).122-128

[3] Wijaya, A., \& Gunawan, G. (2018). Implementasi Algoritma Round Robin Pada Sistem Penjadwalan Mata Kuliah (Studi Kasus: Universitas Muhammadiyah Bengkulu). Jurnal Informatika Upgris, 4(1).

[4] Suktriayu, R. E., Kridalaksana, A. H., \& Hatta, H. R. (2017, September). APLIKASI KAMUS BAHASA PASERINDONESIA BERBASIS ANDROID. In Pros. SAKTI (Seminar Ilmu Komput. dan Teknol. Informasi) (Vol. 2, No. 2, pp. 152-154).

[5] Sarwono, J., Penelitian, L., \& kepada Masyarakat, P. (2008). Strategi Pengumpulan Data Primer Secara Online.

[6] Gunawan, G., \& Cahyani, M. I. (2018). Penerapan Algoritma Kruskal Dalam Mencari Lokasi Anjungan Tunai Mandiri Bank Rakyat Indonesia Cabang Bengkulu Berbasis Android. Journal of Technopreneurship and Information System (JTIS), 1(2), 44-49.

[7] Gunawan, G., \& Prabowo, D. A. (2017). SISTEM UJIAN ONLINE SELEKSI PENERIMAAN MAHASISWA BARU DENGAN PENGACAKAN SOAL MENGGUNAKAN LINEAR CONGRUENT METHOD (Studi Kasus di Universitas Muhammadiyah Bengkulu). Jurnal Informatika Upgris, 3(2). 